\title{
Dynamics of diesel fuel degradation in contaminated soil using organic wastes
}

\author{
A. Dadrasnia $\cdot$ P. Agamuthu
}

Received: 11 July 2011/Revised: 27 December 2011/Accepted: 27 March 2012/Published online: 29 March 2013

(C) Islamic Azad University (IAU) 2013

\begin{abstract}
Bioremediation is an effective measure in dealing with such contamination, particularly those from petroleum hydrocarbon sources. The effect of soil amendments on diesel fuel degradation in soil was studied. Diesel fuel was introduced into the soil at the concentration of $5 \%(\mathrm{w} / \mathrm{w})$ and mixed with three different organic wastes tea leaf, soy cake, and potato skin, for a period of 3 months. Within 84 days, $35 \%$ oil loss was recorded in the unamended polluted soil while 88,81 and $75 \%$ oil loss were recorded in the soil amended with soy cake, potato skin and tea leaf, respectively. Diesel fuel utilizing bacteria counts were significantly high in all organic wastes amended treatments, ranging from $111 \times 106$ to $152 \times 106$ colony forming unit/gram of soil, as compared to the unamended control soil which gave $31 \times 106 \mathrm{CFU} / \mathrm{g}$. The diesel fuel utilizing bacteria isolated from the oil-contaminated soil belongs to Bacillus licheniformis, Ochrobactrum tritici and Staphylococcus sp. Oil-polluted soil amended with soy cake recorded the highest oil biodegradation with a net loss of $53 \%$, as compared to the other treatments. Dehydrogenase enzyme activity, which was assessed by 2,3,5-triphenyltetrazolium chloride technique, correlated significantly with the total petroleum hydrocarbons degradation and accumulation of $\mathrm{CO}_{2}$. First-order kinetic model revealed that soy cake was the best of the three organic wastes used, with biodegradation rate constant of 0.148 day $^{-1}$ and half life of 4.68 days. The results showed there is potential for soy cake, potato skin and tea leaf to enhance biodegradation of diesel in oil-contaminated soil.
\end{abstract}

\footnotetext{
A. Dadrasnia $(\varangle) \cdot$ P. Agamuthu

Institute of Biological Science, Faculty of Science,

University of Malaya, Kuala Lumpur, Malaysia

e-mail: are.dadrasnia@gmail.com
}

Keywords Bioremediation - Diesel fuel · Hydrocarbon · Organic waste

\section{Introduction}

Environmental biotechnology, such as the study of degradation dynamics, is an embodiment of several areas of research that is driven by service and regulation. The extensive utilization of diesel oil as a major source of energy has increased the risks of accidental spills and hence pollution of the environment in the industrialized world. The need to reduce the negative impacts of oil pollution due to spills is motivating many researchers into innovations in various aspects of environmental biotechnology that will usher in sustainable development in environment (Paixão et al. 2007).

In large concentrations, the hydrocarbon molecules that make up crude oil and petroleum products are highly toxic to many organisms, including human (Stroud et al. 2007). It is estimated that between 1.7 and 8.8 million metric tons of oil are released into the world's water and soil every year ((NAS) NAoS 1985; Abu and Dike 2008), $90 \%$ of which is directly related to human activities including deliberate waste disposal. It is also estimated that about $30 \%$ of the spilled oil enters freshwater systems (Henry 2001).

Biological treatment (bioremediation) involves the conversion of toxic chemicals into benign or less toxic chemicals by biological means and typically by employing a single microorganism or a consortium of microorganisms (Pandey et al. 2009; Bustard et al. 2002, 2000; Gupta et al. 2006; Zhao and Poh 2008). The effectiveness of these microorganisms in degrading toxic chemicals depends on their natural, selected or engineered tolerance to the chemicals present during the remediation process. Bioremediation 
can be regarded as an attractive technology that results in partial or complete biotransformation of many organic contaminants. Furthermore, this technology is believed to be cost-effective (Sǎsek et al. 2003; Diplock et al. 2009; Dadrasnia and Agamuthu 2010). As much as the diversity in sources and chemical complexities in organic pollutants exists, there is probably more diversity in microbial members and their capabilities to synthesize or degrade organic compounds (Ramakrishnan et al. 2010, 2011). Some important factors that can limit remediation of polluted soil are nutrient, moisture content, $\mathrm{pH}$ and temperature. Bioremediation of hydrocarbon-contaminated soils, which exploits the use of organic wastes to stimulate microbial activity and degradation of organic contaminants, has been established as an efficient, cost-effective and environmentally sound treatment.

Therefore, the combined action of biostimulation through compost addition and bioaugmentation provided a good result for removal of total petroleum hydrocarbon (TPH) from diesel-contaminated soil (Taccari et al. 2012).

Soil biological methods used to describe microbial activity during the course of bioremediation have been restricted mainly to soil respiration, dehydrogenase activity, and microbial accounts (H-GSaR 1990; Margesin et al. 2000). Remediation of hydrocarbon-contaminated soil using supplements, such as composting or dung as a remediation tool has been considered. The positive effects of $N$ amendment on microbial activity and/or petroleum hydrocarbon degradation have been widely demonstrated (Jørgensen et al. 2000; Margesin et al. 2000, 2007; Riffaldi et al. 2006). The objectives of this study were to investigate the potential of tea leaf, soy cake and potato skin, to enhance biodegradation of diesel fuel in soil. Kinetic model was used to determine the rate of biodegradation of the hydrocarbon in the soil and subsequently to determine the half life of the oil degradation.

Date and location of the research:

This study was carried out on January 2011 in solid waste laboratory, University of Malaya, Kuala Lumpur, Malaysia.

\section{Materials and methods}

\section{Collection of samples and diesel fuel}

Organic wastes used in this study were collected from different locations; tea leaf (TL) and potato skin (Phillips et al. 2006) was collected from the IGS Canteen, University of Malaya, while the soy cake (SC) was made in the laboratory. The soil used in this study (silty loam) was obtained from the garden section of Asia-Europe Institute, University of Malaya, Kuala Lumpur. It was transported to the laboratory and air-dried, finely ground with a mortar and pestle, and sieved through a 2-mm mesh sieve. Diesel fuel was purchased from a petrol station in Petaling Jaya, Malaysia and its profile was analyzed using GC.

\section{Bioremediation treatments}

The range of oil used as a treatment is within $5-25 \%$ as used by many researchers (Ijah and Antai 2003a). $1.5 \mathrm{~kg}$ soil of fresh soil was placed in plastic poly bags labeled A to $E$ and polluted with $5 \%(\mathrm{w} / \mathrm{w})$ diesel fuel $\left(50,000 \mathrm{mg} \mathrm{kg}^{-1}\right)$. This paper, however, only reports results obtained for $5 \%$ oil pollution. After 2 days, $10 \%$ each of the dried organic wastes (TL, SC and PS) were added into each of the oil-polluted soil, labeled A, B and C, respectively. The soils were mixed daily to provide sufficient aeration. The soils were moistened by the addition of water every other day to adjust the water holding capacity to maintain at $60 \%$ throughout the experimental period. This was incubated at room temperature $\left(30 \pm 2{ }^{\circ} \mathrm{C}\right)$. In addition, the control (vessel D) with only soil and diesel fuel and an additional control treatment (E) were autoclaved twice (within the same day at $121{ }^{\circ} \mathrm{C}$ and $15 \mathrm{psi}$ for $1 \mathrm{~h})$ and then $0.5 \%(\mathrm{w} / \mathrm{w}) \mathrm{NaN}_{3}$ was added, to determine the non-biological loss of diesel oil from the soil. All the treatments were set-up in triplicates.

\section{Soil and organic wastes analyses}

Physicochemical properties of soil and organic wastes were determined using standard methods. Nitrogen content (of soil used for bioremediation and organic wastes) was done with Kjeldahl method, organic carbon was determined using APHA 5310 B (Modified) method, $\mathrm{pH}$ and phosphorus were determined with $\mathrm{pH}$ meter (HANNA HI 8424) on 1:2.5 (w/w) soil/distilled water, after $30 \mathrm{~min}$ equilibration and ASTM D 5198-92 method, respectively. Triplicate determinations were made.

\section{Sampling}

The contaminated soils were sampled every 2 weeks for 84 days for determination of total petroleum hydrocarbon in soil. Aerobic heterotrophic bacteria (AHB) and diesel utilizing bacteria (DUB) were isolated, counted and identified.

Enumeration of bacteria in soil

$0.1 \mathrm{ml}$ of serially diluted soil samples was plated on to nutrient agar medium (Oxide) for isolation of aerobic, heterotrophic bacteria with $50 \mu \mathrm{g} / \mathrm{ml}$ fungazol (Williams and Gray 1973) to suppress the growth of fungi. Plates 
were incubated at $30{ }^{\circ} \mathrm{C}$ for $24 \mathrm{~h}$ after which the colonies were counted. Diesel fuel utilizing bacteria in the soil samples were enumerated using oil agar (OA) (Zajic and Supplisson 1972); (1.8 g K $\mathrm{HPO}_{4}, 1.2 \mathrm{~g} \mathrm{KH}_{2} \mathrm{PO}_{4}, 4.0 \mathrm{~g}$ $\mathrm{NH}_{4} \mathrm{Cl}, 0.2 \mathrm{~g} \mathrm{MgSO}_{4} \cdot 7 \mathrm{H} 2 \mathrm{O}, 0.1 \mathrm{~g} \mathrm{NaCl}, 0.01 \mathrm{~g} \mathrm{FeS}-$ $\mathrm{O}_{4} \cdot 7 \mathrm{H}_{2} \mathrm{O}, 20 \mathrm{~g}$ agar, $2 \mathrm{ml}$ diesel fuel, 1,000 ml distilled water). The oil agar plates were incubated for 5 days at $30{ }^{\circ} \mathrm{C}$ before counting the colonies. Bacterial colonies were randomly picked and pure cultures were obtained by repeated sub-culturing on nutrient agar. The bacterial isolates were characterized based on the culture parameters, microscopic techniques and biochemical tests using Biolog Microstation method (Ruan et al. 2005).

Measurement of diesel fuel in soil

The total extent of diesel fuel biodegradation in soil was determined by suspending $10 \mathrm{~g}$ of soil in $20 \mathrm{ml}$ of $n$-hexane in a $250 \mathrm{ml}$ capacity flask. After shaking for $1 \mathrm{~h}$ on an orbital shaker (Model N-Biotek), the solvent-oil mixture was filtered using Whatman number 4 filter paper, into a beaker of known weight and the solvent was completely evaporated by rotary evaporation. The new weight of the beaker consisting of residual oil was recorded. Percentage of degradation of diesel fuel was calculated using the following formula (Ijah and Ukpe 1992) and the initial total petroleum hydrocarbons (TPH in control) was $0.52 \mathrm{~g}$ : biodegradation $=[(\mathrm{TPH}$ control $-\mathrm{TPH}$ treatment $) / \mathrm{TPH}$ control $] \times$ 100 , where TPH is total petroleum hydrocarbon.

The analysis of the residual hydrocarbon in the soil was determined using GC (2010 A) coupled to a mass spectrophotometer QP2010 Plus. Helium carrier gas flow was $1.27 \mathrm{ml} \mathrm{min}^{-1}$. The column oven was initially held at $100{ }^{\circ} \mathrm{C}$ for $2 \mathrm{~min}$, increased to $200{ }^{\circ} \mathrm{C}$ at a rate of $10{ }^{\circ} \mathrm{C}$ $\min ^{-1}$, then to $250{ }^{\circ} \mathrm{C}$ at $20^{\circ} \mathrm{C} \min ^{-1}$ (held for $5 \mathrm{~min}$ ) (Padayachee and Lin 2011).

\section{Dehydrogenase activity}

Soil microbial activity was estimated by dehydrogenase assay. Dehydrogenase activity was determined by monitoring the rate of reduction of 2,3,5-triphenyltetrazolium chloride (INT) as a substrate (Rosa Margesin 2005). $1 \mathrm{~g}$ moist soil samples were weighted in test tubes, mixed with $1.5 \mathrm{~mL}$ of $1 \mathrm{M}$ Tris buffer $(\mathrm{pH} 7.0)$, and $2 \mathrm{~mL}$ of INT solution. Then the test tubes were sealed with screw caps and incubated for $2 \mathrm{~h}$ at $40^{\circ} \mathrm{C}$. After incubation, the developed iodonitrotetrazolium formazan (INTF) was extracted with a mixture of $N, N$-dimethylformamide and ethanol in volume ratio of $1: 1$ and measured spectrophotometrically at $464 \mathrm{~nm}$. The control was prepared with autoclaved soil $\left(121^{\circ} \mathrm{C}, 20 \mathrm{~min}\right)$ and treated as before. The activity was calculated as the amount of INTF produced per hour by subtracting the corresponding control value.

$\mathrm{CO}_{2}$ production

$\mathrm{CO}_{2}$ production was determined by sampling the headspace of sealed Wheaton bottle containing sample of soil, oil and the organic supplement. Air samples $(1 \mathrm{ml})$ were collected from each bottle at $7,14,21,28,35$ and 42 days, and analyzed using gas chromatography (GC-8A) with a thermal conductivity detector (Miles R.A. Miles R.A. D 2001). The GC temperatures were: detector $110{ }^{\circ} \mathrm{C}$, injector $110{ }^{\circ} \mathrm{C}$ and column at $130{ }^{\circ} \mathrm{C}$.

Kinetics of diesel removal and half life

First-order kinetics model used is expressed by the following equation (Chu and Chan 2003):

$\mathrm{C}_{\mathrm{t}}=\mathrm{C}_{\mathrm{i}} \exp (-\mathrm{kt})$

where $C_{t}(\mathrm{mg} / \mathrm{g})$, is the diesel fuel concentration in soil at instant $\mathrm{t}, \mathrm{C}_{\mathrm{i}}(\mathrm{mg} / \mathrm{g})$ is the initial concentration of soil, $\mathrm{k}$ is the rate constants of the first order expressed in $\left(\right.$ day $\left.^{-1}\right)$, and $\mathrm{t}$ (Padayachee and Lin) is the time. The model estimated the biodegradation rate and half life of hydrocarbons in soil relative to treatments applied.

Half life $=\ln (2) / \mathrm{k}$

The data were analyzed for significant differences $(p<0.05)$ between treatments using one-way analyses of variance (Kotrba et al. 2009) with SPSS 18.

\section{Results and discussion}

Physicochemical properties of soil and organic wastes

The physicochemical properties of the investigated soils and organic wastes used in bioremediation are presented in Table 1. It is clear that the soil had low $\mathrm{N}(0.8 \%)$ and $\mathrm{P}$ $(0.6 \%)$ content as compared to organic wastes. The soil used for bioremediation had $\mathrm{C}$ : $\mathrm{N}$ ratio of 16.4. This is a low ratio for effective biodegradation of oil in the soil, hence needed addition of organic wastes as a source of nutrients. Wilfred et al. (2002) reported that stimulated biodegradation of hydrocarbons in soil amended with $2.5 \mathrm{~g}$ of $\mathrm{N}$ per kilogram gives $\mathrm{C}: \mathrm{N}$ ratio greater than 300 (Röling MGM et al. 2002).

Biodegradation of diesel fuel in soil

The level of biodegradation of oil throughout this study is shown in Fig. 1. The total extent of fuel degradation in 
Table 1 Physicochemical properties of soil and organic wastes used for bioremediation

\begin{tabular}{|c|c|c|c|c|}
\hline Parameters & Soil & $\mathrm{TL}$ & $\mathrm{SC}$ & PS \\
\hline Nitrogen $(\%)$ & $0.8 \pm 0.1$ & $1.0 \pm 0.1$ & $1.3 \pm 0.1$ & $1.1 \pm 0.04$ \\
\hline $\begin{array}{l}\text { Phosphorus } \\
\text { (\%) }\end{array}$ & $0.6 \pm 0.5$ & $0.8 \pm 0.7$ & $0.9 \pm 0.9$ & $0.7 \pm 0.1$ \\
\hline $\begin{array}{l}\text { Moisture } \\
\text { content }(\%)\end{array}$ & $10.2 \pm 0.8$ & $34.3 \pm 0.5$ & $75.9 \pm 1.6$ & $62.1 \pm 2.0$ \\
\hline $\begin{array}{l}\text { Organic C } \\
(\%)\end{array}$ & $1.1 \pm 1.3$ & $0.9 \pm 1.2$ & $1.2 \pm 0.9$ & $1.1 \pm 1.1$ \\
\hline $\mathrm{pH}$ & $7.0 \pm 1.5$ & $6.5 \pm 1.2$ & $6.2 \pm 1.2$ & $6.9 \pm 0.5$ \\
\hline Silt (\%) & $70.0 \pm 2.5$ & - & - & - \\
\hline Sand $(\%)$ & $20.0 \pm 1.8$ & - & - & - \\
\hline Clay (\%) & $10.0 \pm 1.6$ & - & - & - \\
\hline Texture & Silty loam & - & - & - \\
\hline
\end{tabular}

$T L$ tea leaf, $S C$ soy cake, $P S$ potato skin

organic waste amended soil ranged between 26 and $88 \%$ after 84 days. This finding is similar to that of, Abioye et al. (2010) who reported that degradation of used lubricating oil using brewery spent grain was more than $90 \%$ within the same period (Abioye et al. 2010). Adesodun and Mbagwu (2008) also showed $83 \%$ waste lubricating oil loss within 3-month period, using piggery waste (Adesodun and Mbagwu 2008).

There was a rapid decrease in total petroleum hydrocarbon (TPH) in all the treatment soils amended with organic wastes as compared to unamended soil. At the end of 14 days, there was 26,32 and $44 \% \mathrm{TPH}$ reduction in soil amended with TL, PS and SC, respectively, as compared to the control soil with $8 \%$ oil degradation (Fig. 1).

At the end of 84 days, soil amended with SC showed the highest decrease $(88 \%)$ in concentration of diesel fuel, followed by soil amended with PS (81\%) while TL amended soil recorded $75 \%$ oil degradation. However, only 35 and $10 \%$ oil loss were recorded in unamended control soil and autoclaved soil at the end of 84 days. Moreover, the addition

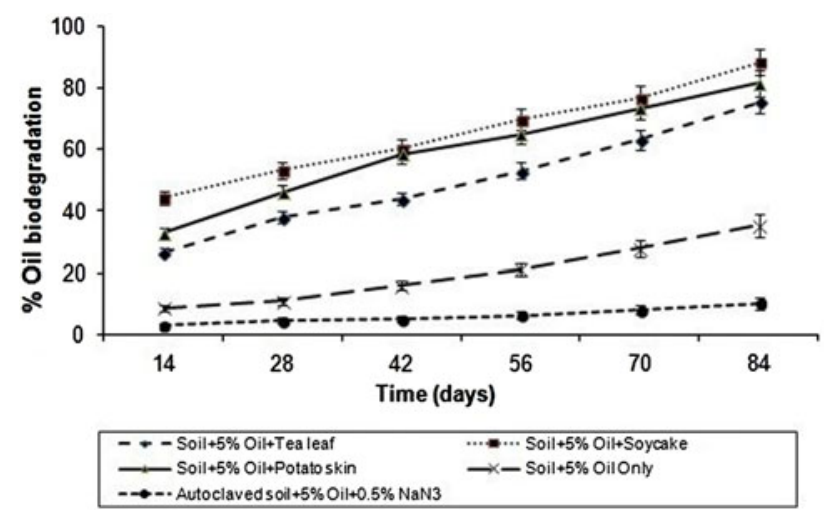

Fig. 1 Percentage biodegradation of diesel fuel in soil with $5 \%$ oil. Vertical bars indicate SE $(n=3)$ of organic wastes promoted significantly $(p<0.05)$ the degradation from 0 to 15 th day (Fig. 1).

Bartha (1986) reported that when oil is applied to soil at rates of $0.5-10 \%$ based on the weight, extensive biodegradation of the oil components occurs within the first 3 months (Bartha 1986). $10 \%$ of the degradation might be due to non-biological factors such as evaporation or photodegradation. This was based on poisoned control soil, i.e., autoclaved-contaminated soil treated with $0.5 \%$ sodium azide. This was contrary to the findings of Palmroth et al. (2002), who recorded as high as $70 \%$ diesel fuel loss within 28 days of study. The differences in these results might be because poisoned control in this study was autoclaved soil mixed with $0.5 \%$ sodium azide, whereas Palmroth et al. (2002) used only $0.5 \%$ sodium azide without autoclaving the soil, thus the sodium azide possibly could not completely sterilize the soil (Palmroth et al. 2002).

The results revealed that the total extent of oil biodegradation in amended soil was about $55 \%$ higher than that of unamended oil polluted soil, indicating that the organic wastes used enhanced biodegradation of diesel fuel in soil. Enhanced biodegradation of used lubricating oil using organic waste has been reported (Adesodun and Mbagwu 2008; Jørgensen et al. 2000; Joo et al. 2007; Ros et al. 2010). Biostimulation by organic waste addition resulted in rapid degradation of TPH in early stage (within 15 days) as compared to control treatments. However, there were significant differences between the organic wastes and the control during the degradation period. The results also indicated that the degradation of oil in soil amended with SC was significantly higher when compared with soil amended with PS and TL $(p<0.05)$. The total extent of diesel fuel biodegradation was about $7 \%$ higher in soil amended with SC than that of PS and about $13 \%$ higher than that of soil amended with TL compared to SC. Thus, proving the effectiveness of SC in enhancing the biodegradation of oil as compared to PS and TL. Statistical analysis showed a significant difference at $(p<0.05)$ between the amended soil and the unamended polluted soil in all the treatments, thus proving the positive contribution of organic wastes to biodegradation of diesel fuel in the soil. Similar results were obtained by Adesodun and Mbagwu (2008), Abioye et al. (2009, 2010) who reported significant differences between the soils amended with melon shell, cow dung and poultry manure and those of unamended spent lubricating oil and crude oil polluted soil (Adesodun and Mbagwu 2008; Abioye et al. 2010; Olabisi Peter Abioye OAAaUJJI 2009; Peter et al. 2009).

Net loss of diesel fuel in the contaminated soil was used to determine the effectiveness of each organic waste (Table 2). The highest loss of TPH was recorded in SC amended soil during the 84 days, followed by PS and TL, respectively. This may be due to the presence and 
bioavailability of nutrient elements like $N(1.35 \%)$ and $P(0.92 \%)$ in SC (Table 2). Nitrogen is known as one of the limiting nutrient necessary for biodegradation of organic pollutants in soil (Barahona et al. 2005). It is also supported by the findings of Joo et al. (2007), who observed that food waste compost addition to contaminated soil, leads to increase in the rate of removal of diesel fuel in soil (Joo et al. 2007). However, the rate of oil breakdown in soil amended with TL was lower than other organic wastes, which may be due to low $\mathrm{pH}$ recorded in soil treated with TL throughout this study period. Low $\mathrm{pH}$ is known to affect the rate of oil breakdown by bacteria in oil-contaminated soil (Okoh 2006). The fate of polluting oil in soil depends on the amount of oil spilled and the time of exposure (Ijah and Antai 2003b). Decreasing degradation rates were associated with increasing oil concentration (Ijah and Antai 2003b).

\section{Enumeration of microbial population}

Active aerobic heterotrophic bacterial colonies (AHB) were recorded in $\mathrm{SC}$ treated soil, ranging from $31 \times 10^{7}$ to $132 \times 10^{7} \mathrm{CFU} / \mathrm{g}$, while AHB counts in PS and TL ranged between $22 \times 10^{7}$ to $116 \times 10^{7} \mathrm{CFU} / \mathrm{g}$ and $15 \times 10^{7}$ to $101 \times 10^{7} \mathrm{CFU} / \mathrm{g}$ of soil, respectively (Fig. 2). Unamended soil (control) gave a range of $5 \times 10^{7}-$ $42 \times 10^{7} \mathrm{CFU} / \mathrm{g}$ of soil. It has been reported by (Hinchee et al. 1995) that when the population of indigenous microorganisms capable of degrading the target contaminant is less than $10^{5}$ colony-forming units $\left(\mathrm{CFUg}^{-1}\right.$ of soil), bioremediation will not occur at a significant rate (Hinchee et al. 1995).

These counts are comparable to those reported by Ijah and Antai (2003b), who observed counts of hydrocarbon degraders in oil polluted soil to be $\times 10^{6} \mathrm{CFU} / \mathrm{g}$ (Ijah and Antai 2003b), but lower than those obtained by (Antai and Mgbomo 1989), whose counts of AUB in hydrocarboncontaminated soil was $\times 10^{8} \mathrm{CFU} / \mathrm{g}$ (Antai and Mgbomo 1989). In fact, the indigenous bacteria capable of degrading hydrocarbons are ubiquitous. However, environmental conditions in diesel fuel-contaminated soil affected the growth of these bacteria. It was reported that oil- contaminated soil with compost or organic waste may promote growth of the indigenous degrader in it (Abioye et al. 2010). Odu (1972) found that the highest application of oil (39\%) to Nigerian soil possessed the highest number of bacteria. AHB counts in this study showed significant levels $(p<0.05)$ between treatments and control, besides there is no significant differences among the organic wastes amended soil (Odu 1972).

Diesel utilizing bacteria (DUB) were more abundant in oil polluted soil amended with different organic wastes than that of unamended polluted soil (Fig. 3). Statistical analysis revealed that there are significant differences in the counts of DUB between the amended soil and unamended soil $(p<0.05)$. Hydrocarbon degrading bacterial populations increased rapidly during the first 14 days of the treatment in all soils, which corresponds to high availability of hydrocarbons during these periods (H-GSaR 1990). The counts of diesel fuel -utilizing bacterial (DUB) in all the soil samples over this period ranged between $2 \times 10^{6}$ and $90 \times 10^{6} \mathrm{CFU} / \mathrm{g}$ of soil. These counts are comparable to those of Antai and Mgbomo (1989), who observed similar counts of hydrocarbon degraders (Antai and Mgbomo 1989). The difference in results may be due to differences in microbial ecology of the soil or characteristics of the experimental soils or type of amendment used.

Generally, the main reason for higher counts of bacteria in SC amended soil can be because of the presence of considerable quantities of $\mathrm{N}$ and $\mathrm{P}$ in $\mathrm{SC}$ which are necessary nutrients for bacterial biodegradative activities (Table 2) (Ijah and Antai 2003a; Joo et al. 2001, 2007; Adesodun and Mbagwu 2008; Kyung-Hwa et al. 2006; Majid et al. 2008).

\section{Identification of bacteria}

The diesel utilizing bacteria (DUB) isolated from the oilcontaminated soil were identified by Biolog method as Bacillus licheniformis, Ochrobactrum tritici and Staphylococcus sp. These bacterial species had been implicated in hydrocarbon degradation by different earlier researchers (Abioye et al. 2010; Bento et al. 2005; Margesin et al.

Table 2 Net loss of total petroleum hydrocarbon (TPH) (\%) in soil during bioremediation

\begin{tabular}{lllllll}
\hline Treatment & \multicolumn{1}{l}{ Time (days) } & & & \\
\cline { 2 - 6 } & 14 & 28 & 42 & 56 & 70 & 84 \\
\hline A & $17.9 \pm 4.8$ & $23.0 \pm 7.0$ & $25.8 \pm 3.7$ & $32.1 \pm 3.5$ & $32.1 \pm 2.1$ & $34.4 \pm 2.6$ \\
B & $35.4 \pm 5.6$ & $45.0 \pm 3.1$ & $47.2 \pm 3.7$ & $49.6 \pm 4.7$ & $48.8 \pm 5.3$ & $55.2 \pm 4.1$ \\
C & $24.0 \pm 3.7$ & $35.1 \pm 5.6$ & $36.4 \pm 4.2$ & $36.8 \pm 2.3$ & $40.3 \pm 3.4$ & $48.3 \pm 6.8$ \\
\hline
\end{tabular}

$\mathrm{A}=$ soil + oil $+\mathrm{TL}, \mathrm{B}=$ soil + oil $+\mathrm{SC}, \mathrm{C}=$ soil + oil + PS. Net $\%$ loss $=\%$ loss in TPH of oil-polluted soil amended with organic wastes- \% loss in TPH of unamended polluted soil 
Fig. 2 Aerobic heterotrophic bacteria (AHB) population in soil. Vertical bars indicate SE $(n=3)$

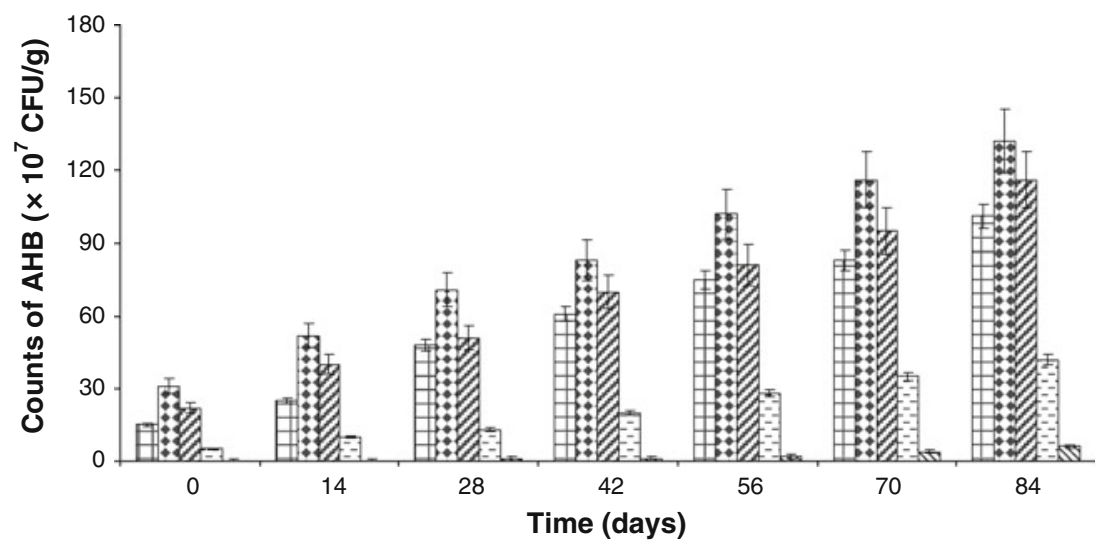

团 Soil+5\%oil+10\%TL

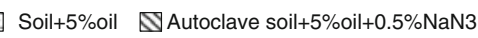

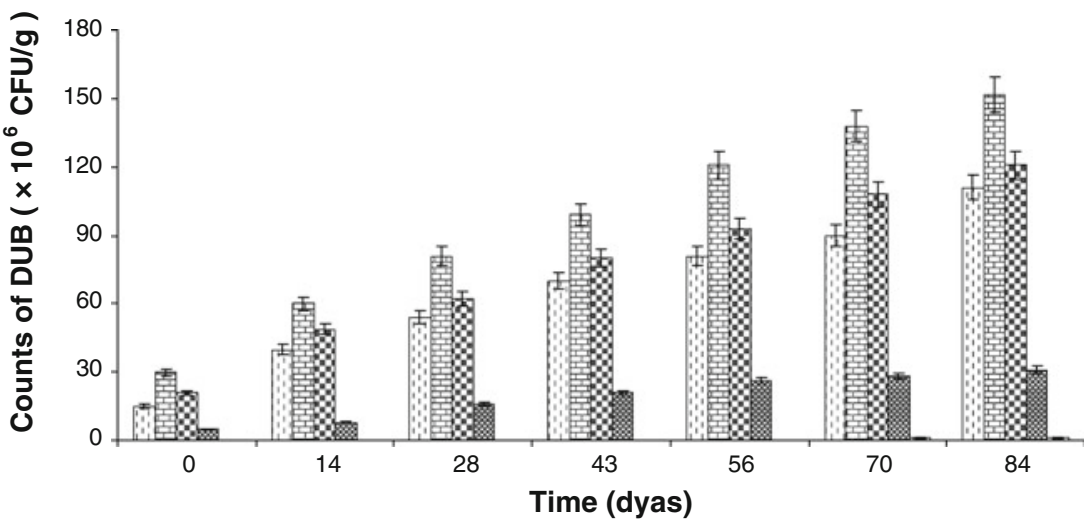

Soil+5\%oil+10\%TL 国Soil+5\%Oil+10\%SC 国 Soil+5\%oil+10\%PS 图 Soil+5\%oil
2007). All the isolates were able to degrade the diesel fuel. Generally, Bacillus sp. grew extensively on the oil agar better than other isolates; this might be due to the presence of efficient hydrocarbon degradative enzyme systems and the presence of catabolic genes involved in hydrocarbon degradation in the bacterial species (Kyung-Hwa et al. 2006; Majid et al. 2008).

Microbial activity

Dehydrogenase enzyme activity has been used to monitor microbial activity as an index for the total oxidative activity (Alef 1995). After starting the experiment dehydrogenase enzyme activity in the TL, SC and PS amended treatments were 172, 210 and $190 \mu \mathrm{g}$ INTF/g dry weight of soil in $2 \mathrm{~h}$, respectively. Dynamic increase in dehydrogenase activity was monitored for the first 28 days for all of amendment experiments (Fig. 4). At the first sampling (28-d), dehydrogenase activity of the contaminated soil with SC showed a value significantly (4.8-fold) higher than that of uncontaminated soil. This may be evidence of an intense initial activity of microorganisms that could have efficiently utilized organic $\mathrm{C}$ of TPH. Therefore, dehydrogenase activity may be used as a parameter representing microbial activity. In 84 days, all of the amendments showed a decrease, this final decrease portably indicated the lack of optimum growth conditions for microorganisms. Increase in microbial activity in this research, indicates that the organism in organic wastes are metabolically active and may contribute to the biodegradation process of TPH (Lee et al. 2008). Higher activity observed in SC amendment soils suggests that this material can be an effective and inexpensive microbial inoculants as well as a nutrient-organic matter source. These results agreed with the findings of Margesin et al. (2000) which showed an initial phase characterized by an increase in dehydrogenase activity in hydrocarbon-contaminated soils (Margesin et al. 2000).

Soil respiration

In general, $\mathrm{CO}_{2}$ evolution has been used as an index representing microbial activity, because $\mathrm{CO}_{2}$ is a by-product 


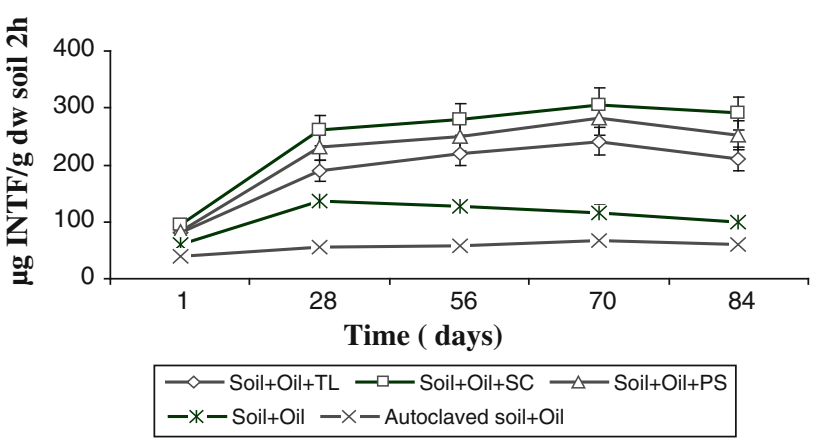

Fig. 4 Dehydrogenase enzyme activity during the experiment. Vertical bars indicate SE $(n=3)$

of organic compound degradation. The cumulative amount of $\mathrm{CO}_{2}$ evolved shows more distinct effect of organic amendments on TPH degradation. The metabolic activity (respiration) of microbes increased significantly. Dramatic increase in $\mathrm{CO}_{2}$ evolution at early stage was probably due to the rapid degradation of TPH at the same period (Fig. 1). In those treatments (TL, SC and PS), where hydrocarbons were added to soil, except for the sterilized-contaminated soil (SCS), it was possible to observe significantly higher values for $\mathrm{CO}_{2}$ evaluation. As evidence of an almost total lack of microbial activity in the sterilized soil, the SCS treatment showed the lowest value of respiration. SC produced treatment with highest value in the 42-day period, so confirming altogether what had been observed throughout the analysis of enzyme activities. Although total amount of $\mathrm{CO}_{2}$ evolved for TL was the lowest among the organic amendments experiments, it was two times greater than that of soil-only experiment (Fig. 5).

Table 3 shows the correlation coefficients among TPH degraded, cumulative $\mathrm{CO}_{2}$ evolved and dehydrogenase activity. Degradation of TPH was significantly related to microbial respiration as measured by $\mathrm{CO}_{2}$ evolution $(r=0.89, p \leq 0.01)$. High positive correlation was also found between TPH degraded and dehydrogenase activity. Significant positive correlation between the amount of $\mathrm{CO}_{2}$ evolved and the dehydrogenase activity was also found $(r=0.87, \quad p \leq 0.01)$ and there was also correlation between TPH and dehydrogenase was $(r=0.91$, $p \leq 0.01)$. This result indicates that the amount of $\mathrm{CO}_{2}$

Table 3 Matrix of correlation coefficients for the parameters used in this research

\begin{tabular}{llll}
\hline & $\begin{array}{l}\text { TPH } \\
\text { degraded }\end{array}$ & $\begin{array}{l}\text { Cumulative } \\
\mathrm{CO}_{2}\end{array}$ & $\begin{array}{l}\text { Dehydrogenase } \\
\text { activity }\end{array}$ \\
\hline TPH degraded & 1.00 & $0.89^{* *}$ & $0.91^{* *}$ \\
$\mathrm{CO}_{2}$ & & 1.00 & $0.87^{* *}$ \\
Dehydrogenase activity & & & 1.00 \\
\hline
\end{tabular}

** Correlation is significant at the 0.01 level

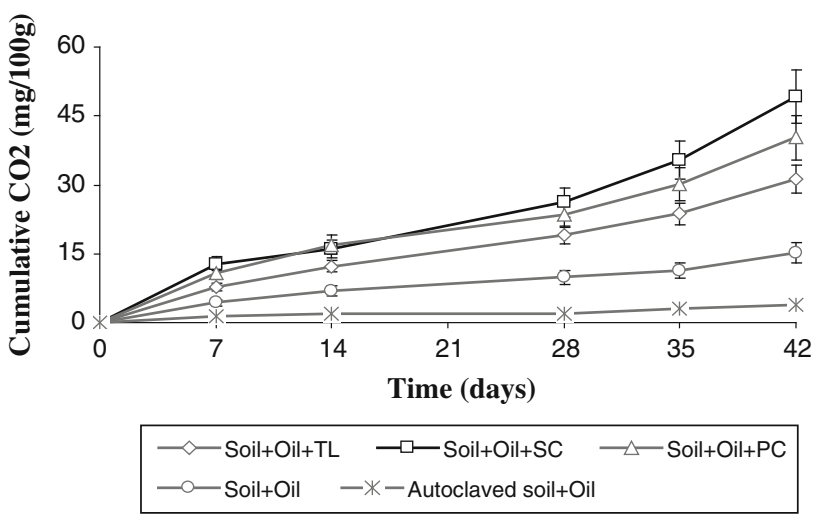

Fig. 5 Concentration of $\mathrm{CO}_{2}$ emitted from in soil treated with diesel oil and amended with organic wastes

evolved and dehydrogenase activity matched well with TPH degradation (MR Mehrasbi1 et al. 2003; Balba et al. 1998).

Kinetics of diesel removal and half life

First-order kinetics model Chu and Chan (2003) was used for determination of biodegradation of used oil in the various treatments (Chu and Chan 2003). Table 4 shows the biodegradation rate constant $(k)$ and half life $\left(t_{1 / 2}\right)$ for the different treatments. Soil amended with SC had the highest biodegradation rate of 0.148 day $^{-1}$ and half life 4.68 days; the biodegradation rate and half life of PS and TL were 0.1286 day $^{-1}$, half life 5.38 days and 0.0972 day $^{-1}$, half life 7.12 days, respectively. The biodegradation rate of unamended control and autoclaved soil were $0.029 \mathrm{day}^{-1}$ and $0.0093 \mathrm{day}^{-1}$, respectively. This result is similar to the findings of Namkoong et al. (2002) who reported higher biodegradation rate constant and low half life in diesel-contaminated soil and amended with 1:0.3 sewage sludge compared to those amended with 1:0.1 under the same conditions (Namkoong et al. 2002). Adesodun and Mbagwu (2008), who showed highest

Table 4 Biodegradation rate and half life of hydrocarbon in oil-polluted soil

\begin{tabular}{llll}
\hline Treatment & $\begin{array}{l}\text { Biodegradation } \\
\text { constant }(k) \mathrm{day}^{-1}\end{array}$ & $\begin{array}{l}\text { Half life } \\
(\text { days }) t_{1 / 2}\end{array}$ & $\begin{array}{l}\text { Coefficient of } \\
\text { determination } \\
R^{2}\end{array}$ \\
\hline $\mathrm{A}$ & 0.0972 & 7.12 & 0.92 \\
$\mathrm{~B}$ & $0.148^{*}$ & 4.68 & 0.98 \\
$\mathrm{C}$ & 0.1286 & 5.38 & 0.89 \\
$\mathrm{D}$ & 0.0291 & 23.77 & 0.87 \\
$\mathrm{E}$ & 0.0093 & 74.29 & 0.90 \\
\hline $\mathrm{A}=$ soil + oil $+\mathrm{TL}, \quad \mathrm{B}=$ soil + oil $+\mathrm{SC}, \mathrm{C}=$ soil + oil $+\mathrm{PS}$ \\
$\mathrm{D}=$ soil +oil E $=$ autoclaved soil + oil $+\mathrm{NaN}$ \\
* Significant difference at the $p<0.05$ level, respectively
\end{tabular}




\section{(a)}

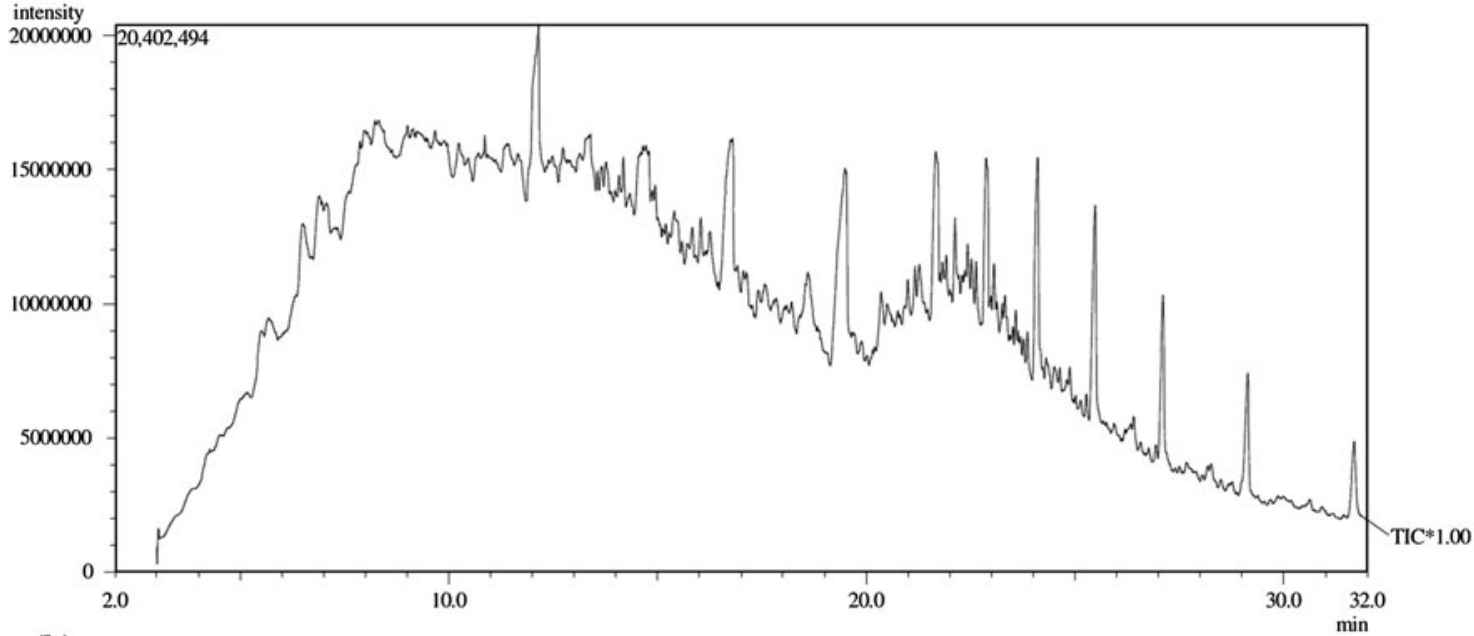

(b)

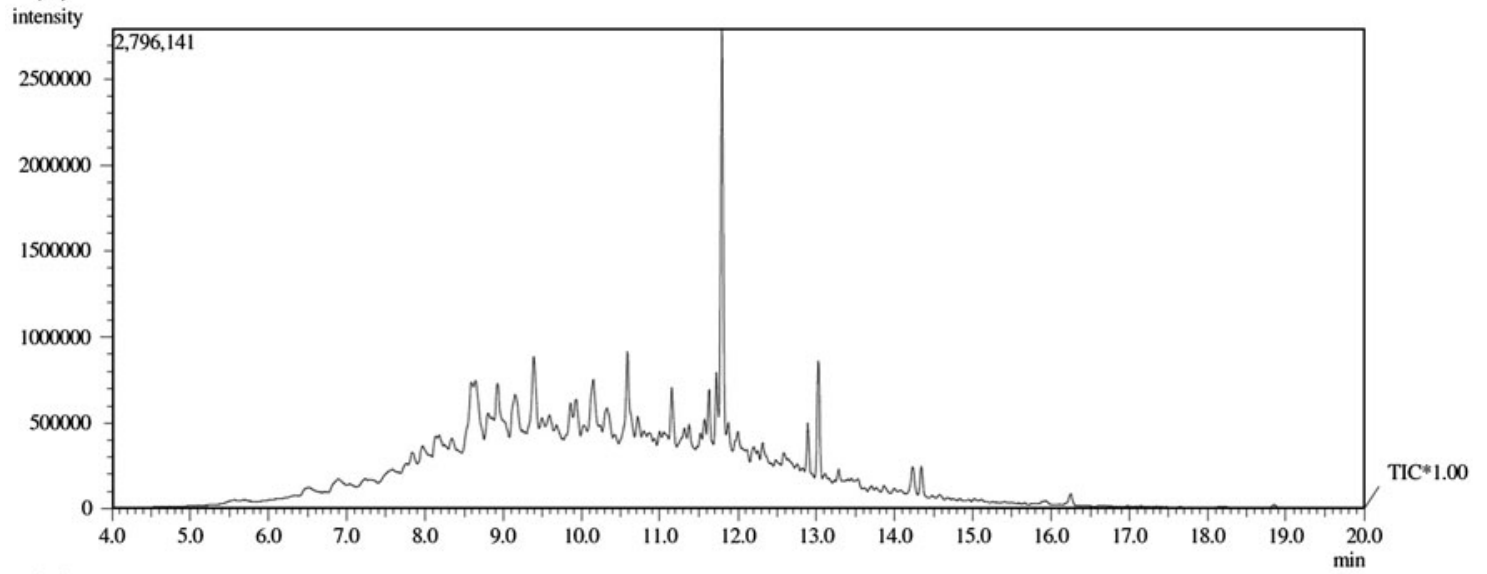

(c)

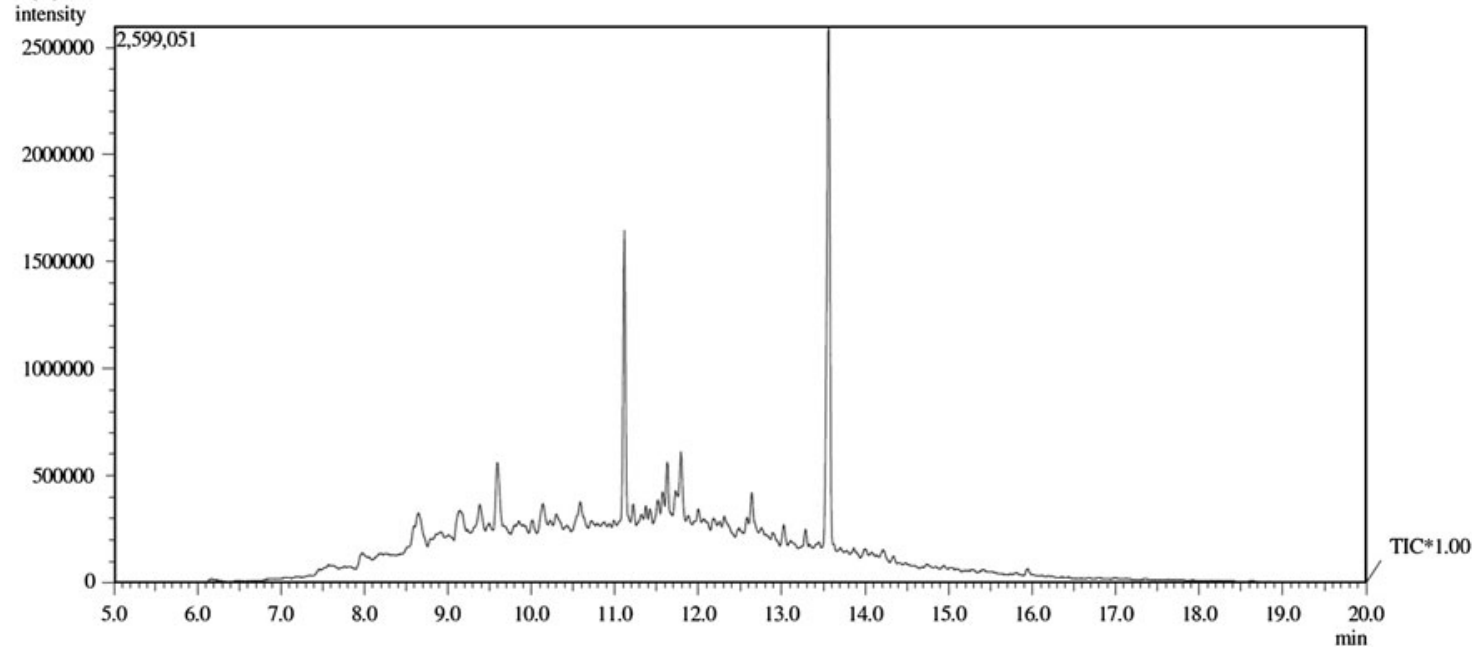

Fig. 6 Chromatogram of residual diesel fuel in soil amended with SC at a 14 days, b 42 days and $\mathbf{c} 84$ days

biodegradation rate in oil-contaminated soil amended with pig wastes, had highest percentage of biodegradation throughout the study period (Adesodun and Mbagwu 2008).

\section{GC-MS analysis}

The substances monitored were analyzed and identified from their mass spectra and retention times, as indicated by 
the chromatogram of the remaining diesel after biodegradation tests. The hydrocarbons above $\mathrm{C}_{14}$ adsorb to the soil particle, which makes them less volatile, and they do not give a detectable concentration in the gas phase when sampling times are as short as those used in this experiment (Dalhammar 1998). Significant reduction in diesel content $\left(\mathrm{C}_{8}-\mathrm{C}_{26}\right)$ was observed in the biostimulation samples as compared to the natural attenuation and the sterilized controls. A decrease in the intensities of hydrocarbon in all SC supplemented was observed, compared with those in the sterilized samples (Fig. 6). The peaks of long chain petroleum hydrocarbons were relatively higher than those of short chain hydrocarbons. Similar results were shown by (Huang et al. 2005).

\section{Conclusion}

Bioremediation, with the addition of amendments, is a viable choice for the remediation of oil-contaminated soil. In this study, a significant reduction in diesel fuel was achieved by adding soy cake, which is a waste from soy bean processing, possibly because it was more effective than other amendments in providing an alternative source of $\mathrm{N}$ and $\mathrm{P}$, in achieving the overall stimulation of microbial activity. AHB counts in all the soil amended with various organic wastes were higher compared to that of unamended control soil. This may be due to differences in microbial ecology of the soil or characteristics of the experimental soils. The reason for higher counts of bacteria in amended soil may be the result of the presence of appreciable quantities of $\mathrm{N}$ and $\mathrm{P}$ in the organic wastes, especially high $\mathrm{N}$ content in $\mathrm{SC}$ which is a necessary nutrient for bacterial biodegradative activities. High correlation $(r=0.91,0.89)$ were found among the amount of TPH degraded, the amount of $\mathrm{CO}_{2}$ evolved, and dehydrogenase activity.

Biodegradation of diesel fuel was high (75-88 \%) in all the soil amended with different organic wastes compared to the unamended soil $(35 \%)$. Kinetic model data in this study showed that the rate of degradation of diesel oil in soil amended with SC was higher than all other treatments. Overall, the differential performance of these organic amendments followed SC $>$ PS $>$ TL.

Acknowledgments This study was supported with the University of Malaya IPPP Grants FP014/2010A and PS300/2010B.

\section{References}

(NAS) NAoS (1985) Oil in the sea; inputs, fates and effects. National academy press, Washangton
Abioye P, Alonge OA, Ijah UJJ (2009) Biodegradation of crude oil in soil amended with melon shell. AU J Technol 13(1):35-38

Abioye P, Abdul Aziz A, Agamuthu P (2010) Enhanced biodegradation of used engine oil in soil amended with organic wastes. Water Air Soil Pollut 209(1):173-179. doi:10.1007/s11270009-0189-3

Abu GO, Dike PO (2008) A study of natural attenuation processes involved in a microcosm model of a crud oil impacted wetland sediment in the Niger delta. Bioresour Technol 9:4761-4767

Adesodun JK, Mbagwu JSC (2008) Biodegradation of waste-lubricating petroleum oil in a tropical alfisol as mediated by animal droppings. Bioresour Technol 99(13):5659-5665

Alef K (1995) Estimation of microbial activities: dehydrogenase activity. In: Alef K, Nannipieri P (eds) Methods in applied soil microbiology and biochemistry. Academic Press, New York, pp 228-231

Antai SP, Mgbomo E (1989) Distribution of hydrocarbon utilizing bacteria in oil-spill areas. Microbios Letters 40:137-143

Balba MT, Al-Awadhi N, Al-Daher R (1998) Bioremediation of oilcontaminated soil: microbiological methods for feasibility assessment and field evaluation. J Microb Methods 32(2): $155-164$

Barahona L, Veg-Loyo L, Guerrero M, Ramirez S, Romero I, VegaJarquin C, Albores A (2005) Ecotoxicological evaluation of diesel-contaminated soil before and after bioremediation process. Environ Toxicol 20(1):100-109

Bartha R (1986) Biotechnology of petroleum pollutant biodegradation. Microb Ecol 12(1):155-172. doi:10.1007/bf02153231

Bento FM, Camargo FAO, Okeke BC, Frankenberger WT (2005) Comparative bioremediation of soils contaminated with diesel oil by natural attenuation, biostimulation and bioaugmentation. Bioresour Technol 96(9):1049-1055

Bustard MT, McEvoy EM, Goodwin JAS, Burgess JG, Wright PC (2000) Biodegradation of propanol and isopropanol by a mixed microbial consortium. Appl Microbiol Biotechnol 54(3):424-431. doi: $10.1007 / \mathrm{s} 002530000398$

Bustard M, Whiting S, Cowan D, Wright P (2002) Biodegradation of high-concentration isopropanol by a solvent-tolerant thermophile Bacillus pallidus. Extremophiles 6(4):319-323. doi:10.1007/ s00792-001-0260-5

Chu W, Chan KH (2003) The mechanism of the surfactant-aided soil washing system for hydrophobic and partial hydrophobic organics. Sci Total Environ 307(1-3):83-92

Dadrasnia A, Agamuthu P (2010) Enhanced degradation of dieselcontaminated soil using organic wastes. Malays J Sci 29: $225-230$

Dalhammar MEáASáG (1998) Biological degradation of diesel fuel in water and soil monitored with solid-phase micro-extraction and GC-MS. Appl Microbiol Biotechnol 50:129-134

Diplock EE, Mardlin DP, Killham KS, Paton GI (2009) Predicting bioremediation of hydrocarbons: laboratory to field scale. Environ Pollut 157(6):1831-1840

Gupta A, Singh R, Khare SK, Gupta MN (2006) A solvent tolerant isolate of Enterobacter aerogenes. Bioresour Technol 97(1): 99-103

Henry T (2001) Contaminated Sediments and the graeat lakes. Microsoft On-line Encyclopdia

H-GSaR Bar (1990) Effects of jet fuel spills on the microbial community of soil. Microb Ecol 56:646-651

Hinchee RE, Fredrickson J. \& Alleman BC (Eds) (1995) In: Bioremediation of chlorinated solvents. Columbus, $\mathrm{OH}$ : Battelle Press

Huang XD, El-Alawi Y, Gurska J, Glick BR, Greenberg BM (2005) A multi-process phytoremediation system for decontamination of persistent total petroleum hydrocarbons (TPHs) from soils. Microchem J 81(1):139-147 
Ijah UJJ, Antai SP (2003a) The potential use of chicken-drop microorganisms for oil spill remediation. Environmentalist 23(1): 89-95. doi:10.1023/a:1022947727324

Ijah UJJ, Antai SP (2003b) Removal of Nigerian light crude oil in soil over a 12-month period. Int Biodeterio Biodeg 51(2):93-99

Ijah UJJ, Ukpe LI (1992) Biodegradation of crude oil by bacillus strains 28A and 61B isolated from oil spilled soil. Waste Manage (Oxford) 12(1):55-60

Joo HS, Phae CG, Ryu JY (2001) Comparison and analysis of characteristics for recycling of multifarious food waste. J KOWREC 9:117-124

Joo HS, Shoda M, Phae CG (2007) Degradation of diesel oil in soil using a food waste composting process. Biodegradation 18(5):597-605. doi:10.1007/s10532-006-9092-4

Jørgensen KS, Puustinen J, Suortti AM (2000) Bioremediation of petroleum hydrocarbon-contaminated soil by composting in biopiles. Environ Pollut 107(2):245-254

Kotrba P, Najmanova J, Macek T, Ruml T, Mackova M (2009) Genetically modified plants in phytoremediation of heavy metal and metalloid soil and sediment pollution. Biotechnol Adv 27(6):799-810

Kyung-Hwa B, Byung-Dae Y, Hee-Mock O, H-SKI-S L (2006) Biodegradation of Aliphatic and Aromatic Hydrocarbons by Nocardia sp H17-1. Geomicrobiol J 23(5):253-259

Lee SH, Oh BI, JG Kim (2008) Effect of various amendments on heavy mineral oil bioremediation and soil microbial activity. Bioresour Technol 99(7):2578-2587

Majid Z, Mnouchehr V, S KA (2008) Naphthalene metabolism in Nocardia otitidiscaviarum strain TSH 1, a moderately thermophilic microorganism. Chemosphere 72:905-909

Margesin R, Zimmerbauer A, Schinner F (2000) Monitoring of bioremediation by soil biological activities. Chemosphere 40(4):339-346

Margesin R, Hämmerle M, Tscherko D (2007) Microbial activity and community composition during bioremediation of diesel-oilcontaminated soil: effects of hydrocarbon concentration, fertilizers, and incubation time. Microb Ecol 53(2):259-269. doi: 10.1007/s00248-006-9136-7

Mehrasbi MR, Haghighi B, Shariat M, Naseri S, Naddafi K (2003) Biodegradation of petroleum hydrocarbons in soil as affected by heating and forced aeration. Iranian J Publ Health 32(3):28-32

Miles RA, D WJ (2001) Assessing the aerobic biodegradability of 14 hydrocarbons in two soils using a simples microcosm/respiration method. Chemosphere 45:1085-1090

Namkoong W, Hwang EY, Park JS, Choi JY (2002) Bioremediation of diesel-contaminated soil with composting. Environ Pollut 119(1):23-31

Odu CTI (1972) Microbiology of soil contaminated with petroleum hydrocarbons. 1. Extent of contamination and some soil microbial properties after contamination. J Inst Petrol 58: 201-208

Okoh IO (2006) Biodegradation alternative in the cleanup of petroleum hydrocarbon pollutants. Biotechnol Mol Biol Rev 1(2):38-50

Olabisi Peter Abioye OAAaUJJI (2009) Biodegradation of crude oil in soil amended with melon shell. AU J Technol 13(1):35-38

Padayachee D, Lin J (2011) The effect of fertilizer amendment on diesel biodegradation in contaminated soils. Afr J Microbiol Res 5(14):1729-1739

Paixão JF, Nascimento IA, Pereira SA, Leite MBL, Carvalho GC, Silveira JJSC, Rebouças M, Matias GRA, Rodrigues ILP (2007) Estimating the gasoline components and formulations toxicity to microalgae (Tetraselmis chuii) and oyster (Crassostrea rhizophorae) embryos: an approach to minimize environmental pollution risk. Environ Res 103(3):365-374
Palmroth MRT, Pichtel J, Puhakka JA (2002) Phytoremediation of subarctic soil contaminated with diesel fuel. Bioresour Technol 84(3):221-228

Pandey J, Chauhan A, Jain RK (2009) Integrative approaches for assessing the ecological sustainability of in situ bioremediation. FEMS Microbiol Rev 33(2):324-375. doi:10.1111/j.1574-6976. 2008.00133.x

Peter Abioye, Alonge OA, Ijah UJJ (2009) Biodegradation of crude oil in soil amended with melon shell. AU J Technol 13(1):35-38

Phillips LA, Greer CW, Germida JJ (2006) Culture-based and cultureindependent assessment of the impact of mixed and single plant treatments on rhizosphere microbial communities in hydrocarbon contaminated flare-pit soil. Soil Biol Biochem 38:28232833

Ramakrishnan B, Megharaj M, Venkateswarlu K, Naidu R, Sethunathan N (2010) The impacts of environmental pollutants on microalgae and cyanobacteria. Crit Rev Environ Sci Technol 40(8):699-821

Ramakrishnan B, Megharaj M, Venkateswarlu K, Sethunathan N, Naidu R (2011) Mixtures of environmental pollutants: effects on microorganisms and their activities in soils. Rev Environ Contam Toxicol 211:63-120

Riffaldi R, Levi-Minzi R, Cardelli R, Palumbo S, Saviozzi A (2006) Soil biological activities in monitoring the bioremediation of diesel oil-contaminated soil. Water Air Soil Pollut 170(1):3-15. doi:10.1007/s11270-006-6328-1

Röling WF, Milner MG, Jones DM, Lee K, Daniel F, Swannell RJ, Head IM (2002) Robust hydrocarbon degradation and dynamics of bacterial communities during nutrient-enhanced oil spill bioremediation. Appl Environ Microbiol 68(11):5537-5548. doi: 10.1128/AEM.68.11.5537-5548.2002

Ros M, Rodríguez I, García C, Hernández T (2010) Microbial communities involved in the bioremediation of an aged recalcitrant hydrocarbon polluted soil by using organic amendments. Bioresour Technol 101:6916-6923

Rosa Margesin FS (2005) Manual of soil analysis-Monitoring and assessing soil bioremediation soil biology, 5 pp 309-320

Ruan A, Min H, Peng X, Huang Z (2005) Isolation and characterization of Pseudomonas sp. strain HF-1, capable of degrading nicotine. Res Microbiol 156(5-6):700-706

Săsek V, Glaser JA, Baveye P (2003) The utilization of bioremediation to reduce soil contamination: problems and solution. In: Nato science series, vol IV. Earth and environmental sciences, Kluwer, Dordrecht

Stroud JL, Paton GI, Semple KT (2007) Microbe-aliphatic hydrocarbon interactions in soil: implications for biodegradation and bioremediation. J Appl Microbiol 102(5):1239-1253. doi: 10.1111/j.1365-2672.2007.03401.x

Taccari M, Milanovic V, Comitini F, Casucci C, Ciani M (2012) Effects of biostimulation and bioaugmentation on diesel removal and bacterial community. Int Biodeterio Biodeg 66(1):39-46

Wilfred FM, Röling L, Michael G, Milner D, Martin J, Kenneth L, (2002) Robust hydrocarbon degradation and dynamics of bacterial communities during nutrient enhanced oil spill bioremediation. Appl Environ Microbiol 68(11):5537-5548

Williams ST, Gray TRG (1973) General principles and problems of soil sampling. In: Broad RG, Lovelock DW (eds) sampling, microbiological monitoring of environments. Academic Press, London, pp 66-100

Zajic JE, Supplisson B (1972) Emulsification and degradation of "Bunker C" fuel oil by microorganisms. Biotechnol Bioeng 14(3):331-343. doi:10.1002/bit.260140306

Zhao B, Poh CL (2008) Insights into environmental bioremediation by microorganisms through functional genomics and proteomics. Proteomics 8(4):874-881. doi:10.1002/pmic.200701005 